Historic, Archive Document

Do not assume content reflects current scientific knowledge, policies, or practices. 

L I B F A Y RECEIVED $x$

U. S. Department of Agriculture.

\section{TWENTIETH CENTURY FRUITS}

Never in the history of mankind has there been offered a list of such valuable new fruits as those herein described

Burbank's

Experiment

Farms 


\section{PRICES}

The time and expense involved in the production and introduction of these new fruits have been great, as those acquainted with the facts are well aware, but it is my aim to place these new varieties in the hands of growers as quickly as possible and at as low prices as is consistent with sound business, in at least, partially repaying for their production and introduction. The expense of properly packing a tree or two for safe delivery to my customers is almost as great as that for packing twenty or a hundred trees. No charges for packing are made on any of these trees.

Today they are ours, tomorrow they may be yours. Order at once, for the very good reason that the stock of most of these varieties is quite limited.

SELECT GRAFTING WOOD of the new fruits mentioned in this list can be supplied in limited quantities at any time before January 15 th. Four feet of grafting wood for the price of a tree of the same variety, or one foot for one-third the price per tree. Special low prices for larger lots while available. Good well-ripened wood and good measure.

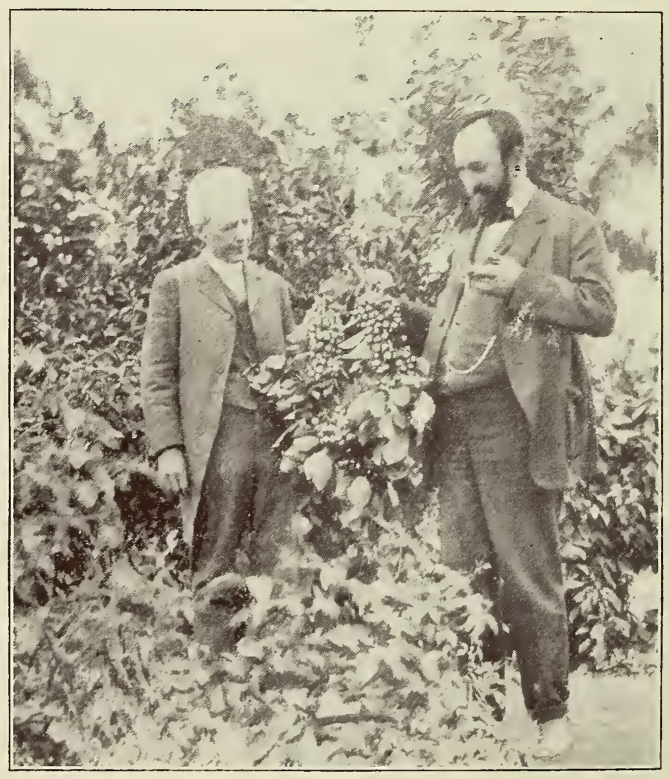

W. Atlee Burpee, the Great American Seedman, testing the "Abundance" Cherries. He says, "Never before have I seen cherries in such abundance or of such large size and superior quality." 


\section{Twentieth Century Fruits}

$\mathrm{T}$

HE TREES offered in this list are absolutely new creations. None like them exist on this earth. All are early bearers, in fact, hundreds of the very trees offered you this season, though generally only one year old, have borne delicious fruit freely during the past summer all along the nursery rows. It took more than twenty years to instill this character of early and perpetual bearing into these trees.

"How to Judge Novelties, look to their source," and also if possible purchase direct from the originator, as many new trees, plants and seeds are grossly misrepresented by a few dealers who trade on the reputation of reliable firms, often doing a thriving business by selling trees and plants in localities where they very well know that they cannot thrive; this and the substitution of inferior or wholly worthless trees or plants under the name and reputation of good ones has been, and is now being carried on persistently and systematically by several parties who victimize those who deal with them by trading on the reputations of reliable firms and good trees.

It should be the duty and privilege of every good citizen to aid in exposing and routing all who are obtaining money under these false pretenses.

Having been in business almost forty years, millions of trees raised in my establishment are now bearing fruit, not only in the Western United States, but everywhere on earth where the sun shines and trees can be grown. I have yet to have a customer complain that the variety was not as represented. Does this record mean anything, and is it surprising that such a reputation should be worth trading on? Counterfeit coins are not counterfeited-it is the genuine ones that are misrepresented.

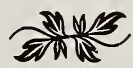

In presenting this list of fruit trees, I wish to thank the friends and customers who have in some cases been purchasers for forty years or more. It is exceedingly pleasing to know that the trees produced in and introduced from this establishment have now become Standards in every country, bearing fruit by carloads in the Eastern, as well as this Western Hemisphere, and in the Southern as well as in this Northern half of the world. No one who knows them questions their value, and perhaps nothing during the past century has more influenced the trend of horticulture, or has tended more to remove horticulture from a small branch of agriculture to a veritable science by itself. 


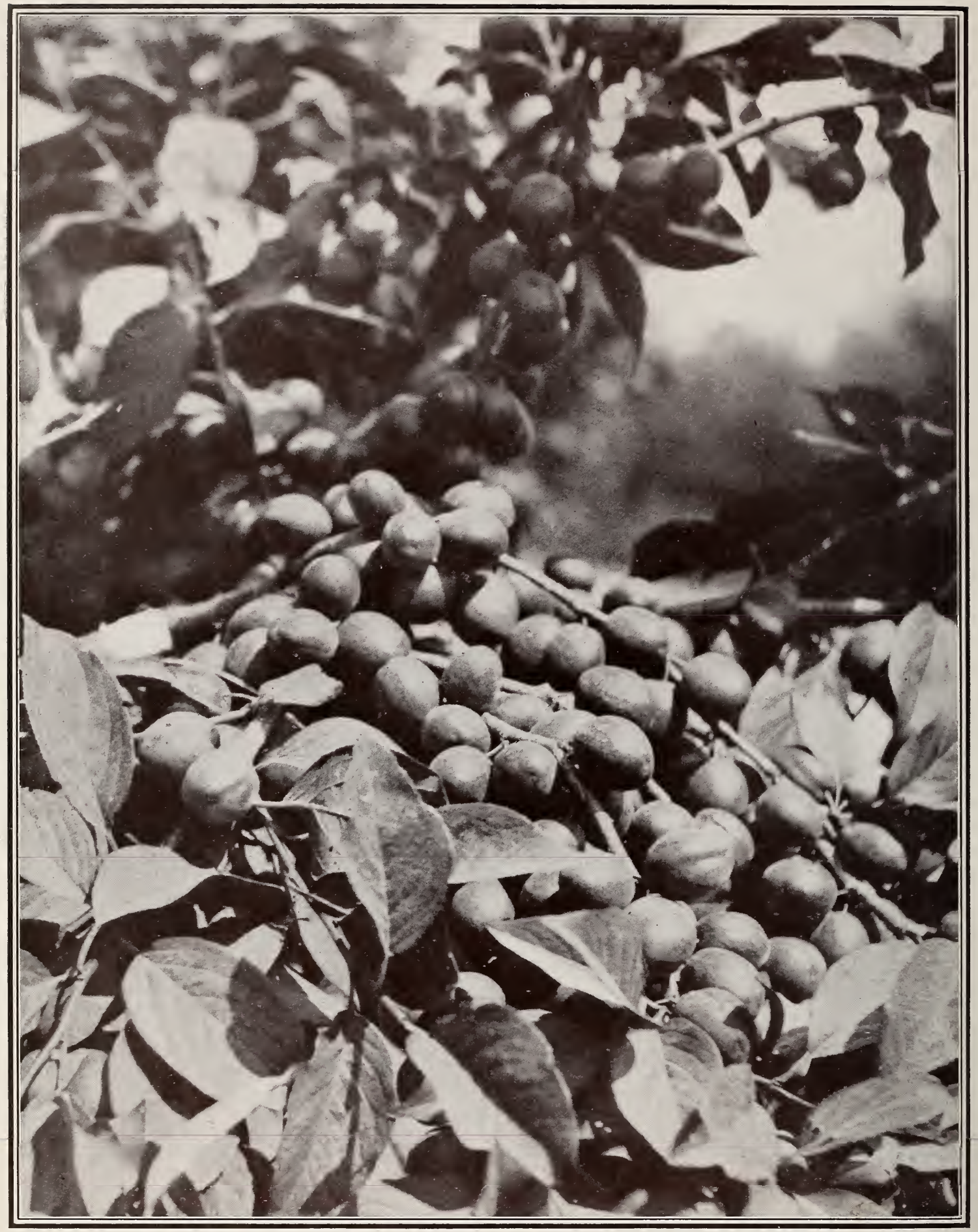

THE NEW “STA NDARD” PRU N E 


\section{A New Prune-The "Standard"}

Years ago I had made the combination of the Tragedy and the Sugar Prume and now have at last (in my opinion and the opinion of a number of the best known growers) the best prune ever produced. The trees are enormous and never-failing bearers, and good, healthy growers. Well grown fruits measure four and a half inches around one way by nearly six inches the long way. Skin purple, with a heavy blue bloom; flesh amber or honey yellow, fine grained, juicy yet firmer than most other drying prunes, very sweet and a perfect freestone.

This is without doubt the best combination drying and shipping prune ever grown; ripens September 1st and has been kept fully a month in good condition in a basket in an ordinary living-room during our warm Fall weather, and can be shipped when dead ripe with success to any part of the United States. And the final test as a prune is that when dipped as usual the result is a big quickly dried prune of better quality than any ever before known. I have no other and know of no other prune which compares with this in its wonderful combination of good qualities.

"It has been tried in a commercial way now, for two years, and its possibilities as a high-grade prune have been established beyond a question of a doubt.',

\section{University of California, College of Agriculture \\ Agr. Experiment Station Berkeley, Calif.}

Examination of Tragedy X Sugar Prune (The "Standard") sample sent by Luther Burbank, Santa Rosa, California.

Description by Prof. E. J. Wickson:-Freestone, Pit small, 5/8" x 3/8". Flesh yellowish, melting, fine grained; very juicy and sweet. Skin dark blue-sub-color dark red, medium texture.

\section{ANALYSIS}

\begin{tabular}{|c|c|c|}
\hline \multirow{2}{*}{ AINALINIS } & \multirow[b]{2}{*}{ The "Standard", } & \multirow{2}{*}{ Average } \\
\hline & & \\
\hline Average weight in grams......... & 49.7 & 23.6 \\
\hline Number per pound...................... & 9.1 & 19.1 \\
\hline Flesh, per cent. $\ldots \ldots \ldots \ldots \ldots \ldots \ldots \ldots \ldots \ldots$ & 96.5 & 94.2 \\
\hline Pit, per cent. $\ldots \ldots \ldots \ldots \ldots \ldots \ldots \ldots \ldots \ldots \ldots$ & 3.5 & 5.8 \\
\hline 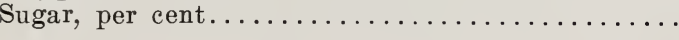 & 18.9 & 18.5 \\
\hline & (Signed) & $\begin{array}{l}\text { COLBY, } \\
\text { f. Chemistry. }\end{array}$ \\
\hline
\end{tabular}

By analysis it will be noticed that it excels the French Prune in every point. (The analysis this season (1911) gave a still greater per cent of sugar and the fruit averaged even larger.)

Trees, each $\$ 3$; two, $\$ 5$; ten or over, $\$ 2$ each.

For those who have orchards it is generally better to use grafting wood to change unprofitable peach, almond or plum trees (on all of which the "Standard" thrives); by this means fruit is produced the second season and samples often the first, and much valuable wood may be produced for the next season's nursery or orchard grafting or sale; many 
thousand acres of heretofore unprofitable orchards are now producing abundantly of the very choicest and most salable fruits (and shipped East by the carload) from grafting wood of new varieties which have originated on my experiment farms in the past.

"'Sample of your grand new prune 'Standard' received to-day. 'Beautiful!' say all to whom I have shown it.

"Perfect in shape and color, as well as all that could be desired in size, it is rightly named 'Standard.'

"Will the wood be for sale this fall? And if so, where? I want some of the first issued to the public.

"'Am sending you samples of cured 'Opulent'; we like them better than any other cured or fresh peach.

$$
\text { “'J. T. G., Morgan Hill, Cal., Sept. 6, 1910.', }
$$

"The best prune when cooked that I ever tasted." -Judge S. F. L., San Jose, Cal.

“Morgan Hill, Cal., Sept. 6, 1910.

"The 'Standard' prune is a wonderful fruit; its perfect shape, deep black color, fine flavor and richness are all that could be desired in a fresh prune, and am sure it will cure nicely. If I like it as well when cured as I do your 'Sugar,' I'll call it a better prune, on account of the pit, which is smaller and smoother, not having the sharp edge (which is about the only fault I have to find with the 'Sugar' prune), and also on account of its wonderful keeping qualities. Regarding the 'Sugar' prune, am pleased to be able to write I like it better every year. The trees are as shapely to-day as they were after the first crop. The fruit is larger, blacker, and richer in flavor each succeeding year. I regret the fact that I did not know enough to graft my 'cot trees to 'Sugar' the same time I grafted my French prune trees to it. If the 'Sugar' prune 20/30's and 30/40's were sold on its merits under its own name, instead of its identity being lost when the packer gets it, am confident it would soon be the favorite in the market.

$$
\text { "J. T. G.", }
$$

"I have delayed acknowledging receipt of the samples of the new prunes (the 'Standard') which you kindly sent me, as I desired to taste them at their best, and when they arrived they were not quite ripe. I tested them at various stages, and after about ten days from the date of receiving them, they were in best condition. Certainly they are choice to eat when ripe in their fresh state; and I can readily understand they must make a most delicious prune when dried.

$$
\text { “'J. L. N., Menlo Park, Cal., Sept. 10, 1909.', }
$$

Five days later I sent to Mr. N. half a dozen of the dried "Standards"; he replied as follows:

Sept. 15, 1909.

"This prune (the 'Standard') is truly delicious. I have never eaten anything more delicious in my life.' -J. L. N. 


\section{A New Cherry-The "Burbank"}

The earliest of all large cherries. The largest of all early cherries, and not only the best of all early cherries, but unsurpassed by any cherry of any season.

The "Burbank" brought in the Eastern States at the wholesale public auction sales in 1908, fifteen dollars per ten-pound box, and seven dollars and fifty cents per ten-pound box later in carload lots, and in 1909 sold

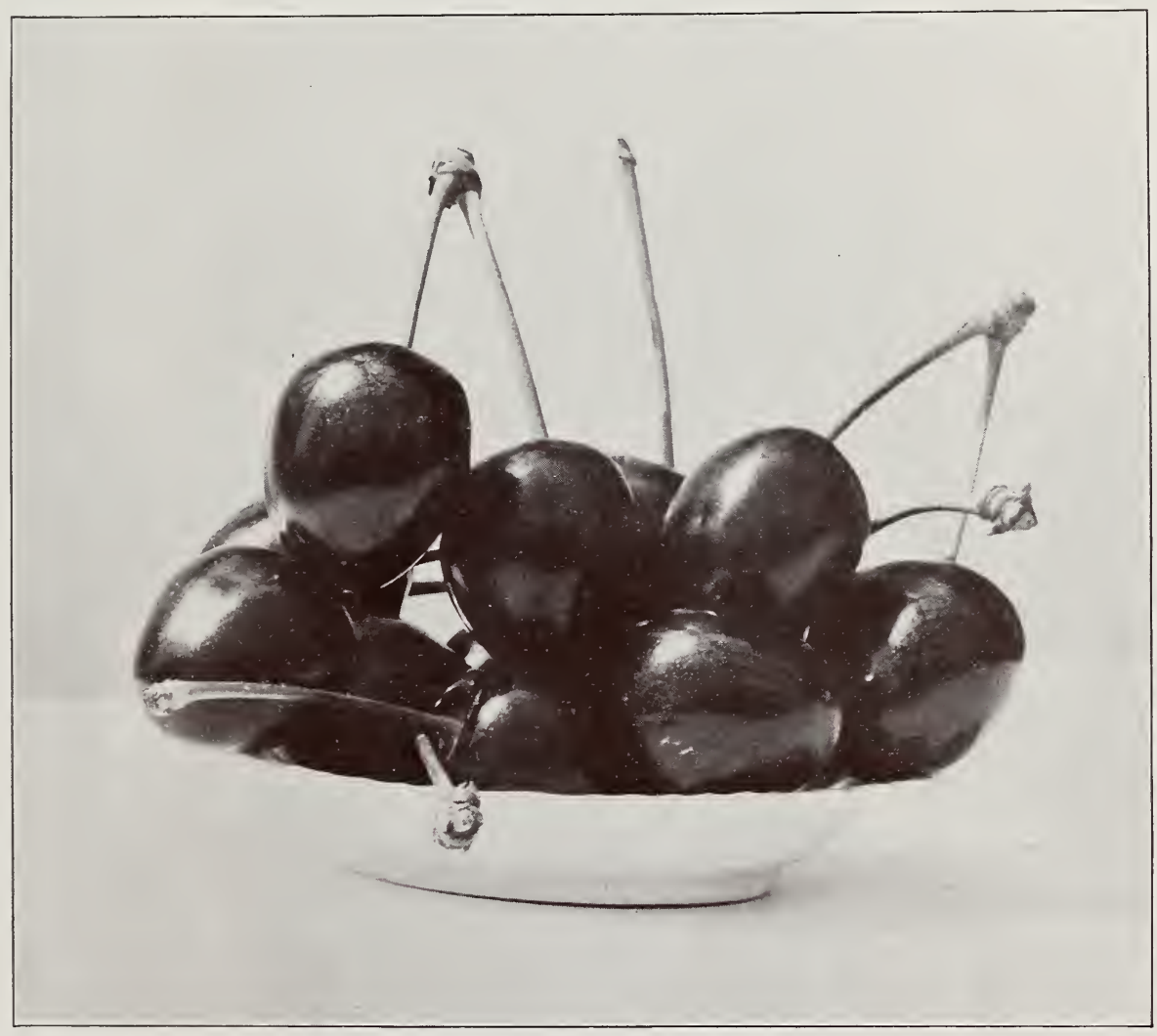

"B U R B A N K,

(Nearly Natural Size.)

again in Philadelphia at the fabulous price of Thirty-one Dollars per box of ten pounds. Just three dollars and ten cents per pound wholesale.

The trees are models in form, vigor and never-failing productiveness.

The foliage, which is of unusual size, is so placed that the fruit is fully protected from birds and cracking by late Spring rains.

The fruit is extremely large for an early cherry, attractive deep crimson color, and of superior quality.

The "Burbank" is THE early cherry.

Only a few large one-year-old trees for sale this season, $\$ 1$ each; ten for $\$ 7$. 


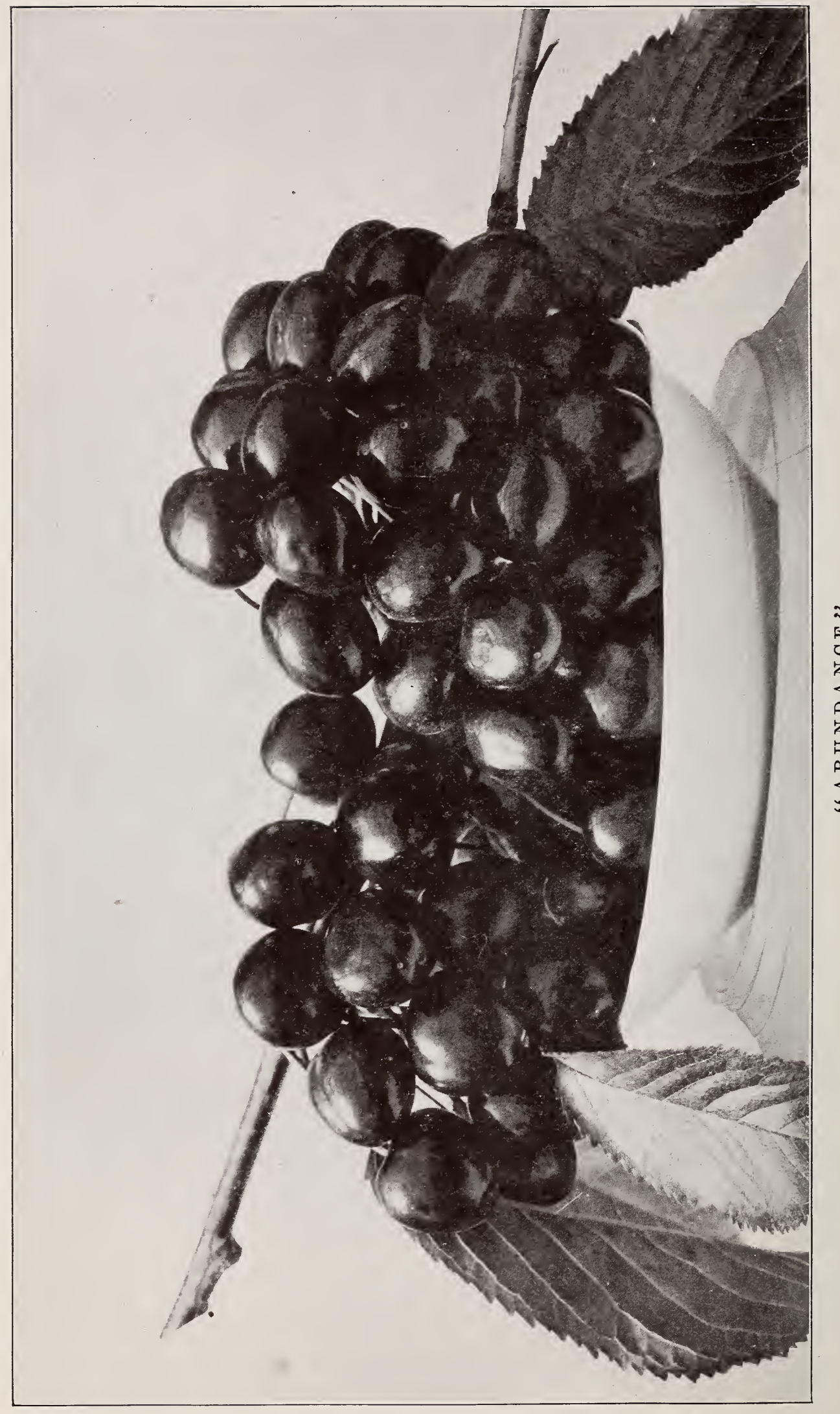

2
19
0
7
4
0
2
5
0
0
4
$\vdots$ 


\section{A New Cherry-“Abundance"}

\section{Seedling of Napoleon (Royal Ann).}

Tree a strong grower and an early and never-failing bearer of very heavy crops. Fully twice as productive as its parent-in other words, onehalf acre of ABUNDANCE trees will produce as many boxes of marketable cherries as an acre of "Royal Ann."

Fruit larger, handsomer, as firm, better form and color, sweeter and far more delicious, never cracks. Better in all respects. When canned, in appearance and flavor wholly unequaled, the very best, most reliable and most productive late cherry for shipping. Ripens one week later than "Napoleon," just right for the canners.

Trees, each $\$ 3$; two for $\$ 5$; per ten, $\$ 20$.

\section{New Hybrid Plum-“Beauty"}

It has been five years since I have introduced a plum; meantime innumerable complicated hybrids have been grown and tested each season, and now a new plum is offered which will become another standard for shipping, the "BEAUTY." It is the product of a very complicated heredity including several species.

Tree a most remarkably vigorous upright grower, like the well known Formosa, with unusually large, healthy foliage. Never failing bearer of full crops of the most beautiful oval crimson fruit two by two and one-quarter inches in diameter. "BEAUTY", like "Santa Rosa" has flesh light crimson, shaded amber. Is the largest of the early plums and those who know it are preparing to plant it very extensively for shipping to Eastern markets for while quite juicy when fully ripe, yet it has a remarkably tough skin and when picked green keeps well, colors up well and develops its delicious flavor. Ripe here June 25th to July 1 st.

Trees, each $\$ 2$; two, $\$ 3$; per ten, $\$ 10$.

\section{New Hybrid Plum-“Geewhiz"}

One of the most delicious of the many seedlings of my hybrid "America" which, with "Gold" was introduced in 1898. This and "Gold" both of which originated on my farms, were the first hybrids ever produced by crossing the American and Japanese species of plums. Both have proved as hardy in the far north as the natives, and being much larger and handsomer, have been widely grown. "GEEWHIZ," while inheriting all their good qualities, is larger, handsomer and incomparably more delicious. No plum now known surpasses it in quality.

Fruit globular, two inches in diameter, crimson blush with numerous crimson dots on yellow ground. Flesh firm, pale amber, apricot-like in 
texture. Exquisitely rich, freestone, good keeper, ripens early-July 25th to August 10th.

Trees, each $\$ 1$; two, $\$ 1.75$; per ten, $\$ 7$.

\section{A New Hybrid Plum-"Victory"}

Another seedling of my hybrid America.

Tree a good strong grower, excelling most of the native plums, good regular bearer.

Fruit nearly globular, pure crimson. Flesh pale amber, peach-like in texture, dry, rich, sweet, delicious. Small stone, half cling. Good keeper. Ripe July 20th to August 5th. Especially good for home use and market. Far better than any Japan plum, far larger than the hardy natives.

Trees, each $\$ 1$; two, $\$ 1.75$; per ten, $\$ 7$.

\section{A New Hybrid Plum-"Choice"}

Another America Seedling.

Tree enormous upright grower and great bearer.

Fruit globular, above two inches in diameter, pure lemon yellow, clingstone. Flesh, golden yellow, firm, rich, subacid, superlatively handsome, extra good keeper and no doubt will be one of the best of plums for shipping as well as one of the hardiest trees known. Ripe, July 25th to August 5th.

All these three new America wonders have been fully tested through the past seven years, and will be found to fill the descriptions above to the letter. No hardy plums ever before offered have equal quality, size, beauty, hardiness and productiveness in combination.

Trees, each $\$ 1$; two, $\$ 1.75$; per ten, $\$ 7$.

\section{A New Plum-The "Prize"}

Seedling of the "Bartlett." The trees grow strong, upright, handsome, and compact with sturdy branches, bearing without fail each season great quantities of large, firm, pure rich deep crimson, almond-formed fruits measuring seven inches around one way by six the other, with a rich, sweet, firm yellow flesh. Freestone, ripening here August 10th. Thoroughly tested during the past six years. Among the best of all the few really good shipping plums.

Trees, each $\$ 1$; two, $\$ 1.75$; per ten, $\$ 7$.

\section{A New Plum-"Pasha"}

Tree strong grower, tremendously productive. Fruit seven by seven and one-half inches in circumference, oval, light crimson; flesh yellow, 
rich, juicy and sweet, freestone. Ripens rapidly August 10th to 20th. Remarkable for size and productiveness. Useful for home and near markets.

This very large, handsome plum originated in 1897 and has been well tested for eleven years. Tree a good upright grower and never-failing bearer; firm until fully ripe when it becomes soft unfitting it for a shipping plum, but owing to its great size and bearing qualities will find a welcome place in every home garden.

\section{A New Plum-"Vesta"}

Tree a strong, spreading grower and remarkably productive.

Fruit very large, oval, two by two and one-fourth inches in diameter. Handsomely marbled crimson and orange. Freestone, firm, sweet, delicious. Good keeper. For shipping and home use one of the best.

Trees, each $\$ 1$; two, $\$ 1.75$; per ten, $\$ 7$.

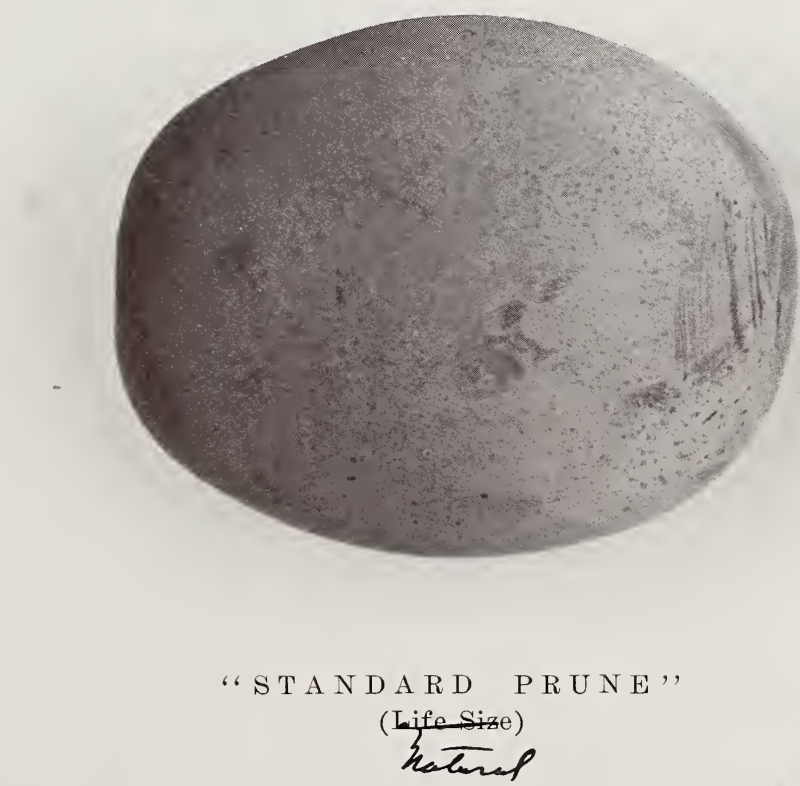

\section{New Stoneless Prune-The "Conquest"}

There has been known for several hundred years a wild plum, an unproductive thorny bush, which bore insignificant acrid, bitter, wild berrylike fruits with only half or two-thirds of a stone. Years ago we had this hunted up in Europe with the plan in view of producing really stoneless plums and prunes. The labor and expense incurred in these experiments have been enormous, but among thousands of seedlings, one really good 


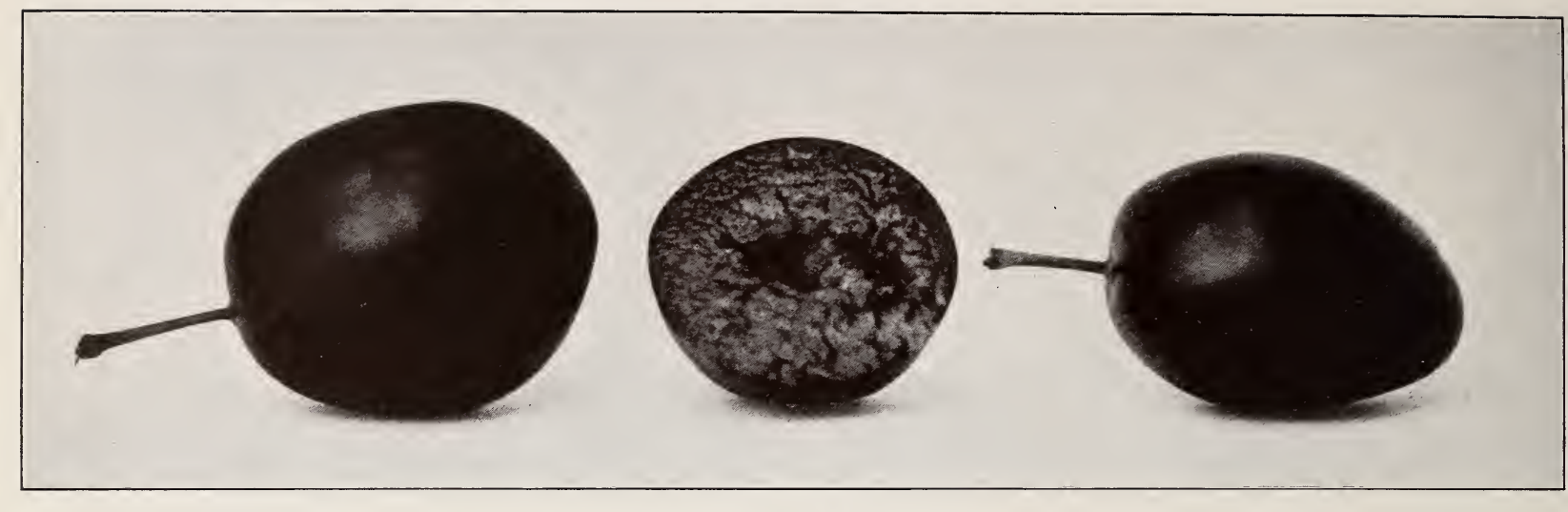

" C O N Q U E T ",

stoneless prune was produced and is here offered for the first time in the history of this earth.

The tree is a vigorous, healthy, rapid grower and unusually productive. The fruit is very similar to its civilized parent, the common French prune, in form, size, color and golden sweet rich flesh. The stone has been eliminated wholly with the exception of a tiny speck. The fruit is so very valuable and the tree so very productive that I have consented to introduce it this season. Ripens with the common French prune and is in all respects very much like it in size, quality and appearance.

Trees, each $\$ 1$; two, $\$ 1.75$; per ten, $\$ 7$.

\section{A New Plum-“Nixie"}

The best of the Pacific Coast Prunus subcordata (Sierra plum) have always been preferred in this land of plums and prunes to other of the thousands in cultivation for its unique quality, especially for jams, sauces and preserving for home use; when cooked having the flavor and appearance of cranberries. This native fruit was quite small and borne on dwarf bushes which were quite often weighted to the ground with the loads of crimson or yellow fruit. For more than twenty years we have sought to place this splendid fruit on a tree of respectable size and civilized appearance. For this labor we have one variety, the "Nixie," which will for all time make a most pleasing addition to the list of plums. "Nixie" is, in fact, the forerunner of a wholly new class of fruits.

Tree a fairly good compact grower, remarkable bearer. Fruit nearly globular, one and one-half inches in diameter, most brilliant scarlet; flesh, deep golden yellow, firm, exceedingly sweet and almost incomparably delicious. Some pronounce it the "best of all plums." Freestone. Ripe August 15th to 25th. No other plum can take the place of this for home use.

Trees, each $\$ 1$; two, $\$ 1.75$; per ten, $\$ 7$. 


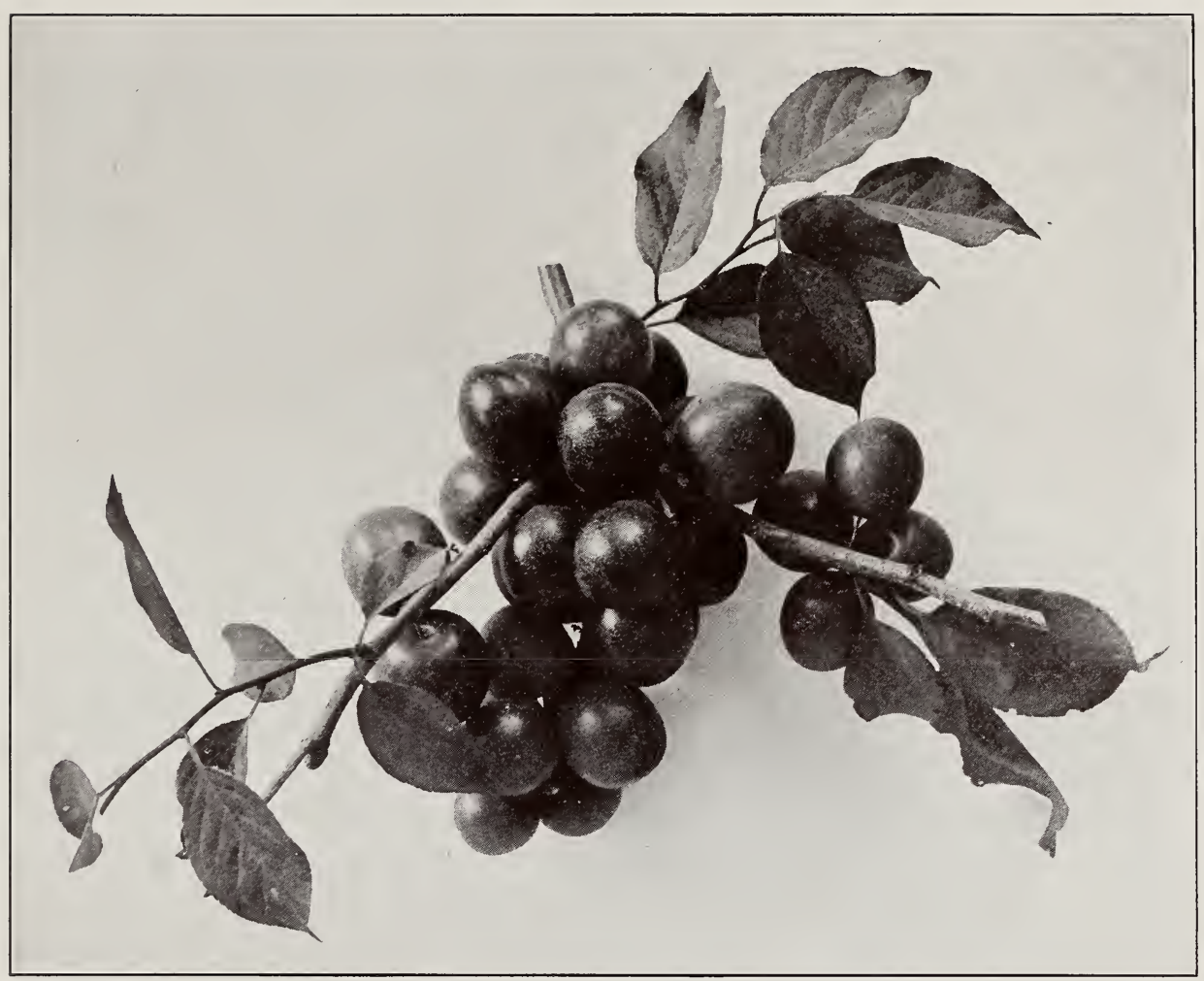

" $\mathrm{EPOCH} "$

\section{A New Hardy Plum-“Epoch"}

"Epoch" should be one of the hardiest of all known plums as it is a cross of the western Sand Cherry (Prunus Besseyi) and America plum, both being about as near "Arctic" plums as can be mentioned.

The tree is a compact grower, dwarf, with dark brown wood, which always, without fail, produces ropes of fruit, each fruit one and a half inches in diameter, beautiful crimson, with shades and dots of yellow. Flesh pure deep yellow, firm with a rich cranberry flavor, but sweeter, and when ripe very good. Ripens August 15th. The youngest, as well as the oldest, trees literally cover themselves with fruit, which keeps remarkably. Probably the most productive and best of all the "Iron Clad," extremely hardy dwarf plums.

Trees, each $\$ 1$; two, $\$ 1.75$; per ten, $\$ 7$. 


\section{THE NEW PLUMCOTS}

The Plumeots are absolutely'new fruits, first produced on my farms some twenty years ago. A great amount of care and expense have been expended on them since and now I have the pleasure of announcing these three plumcots which will be widely grown in all countries where apricots or plums can be grown.

\section{New Plumcot-The "Apex"}

This wonderful new fruit ripens with the very earliest of all the early plums, long before any other good plum or apricot (here June 15th), which would bring its season about three weeks earlier inland. The tree is a stout, compact, upright grower and has never failed to carry a full crop, even where apricots of all kinds cannot be grown and in seasons when many plums were failures. The fruit is extremely handsome and very large for an early fruit, globular, five and one-half to six inches around each way, beautiful deep pink or light crimson; freestone; flesh honey-yellow, firm, rich, aromatic, apricot-like; wholly unequaled in its combination of size, beauty, productiveness and quality by any other early fruit of any kind.

Trees, each $\$ 3$; two, $\$ 5$; per ten, $\$ 20$.

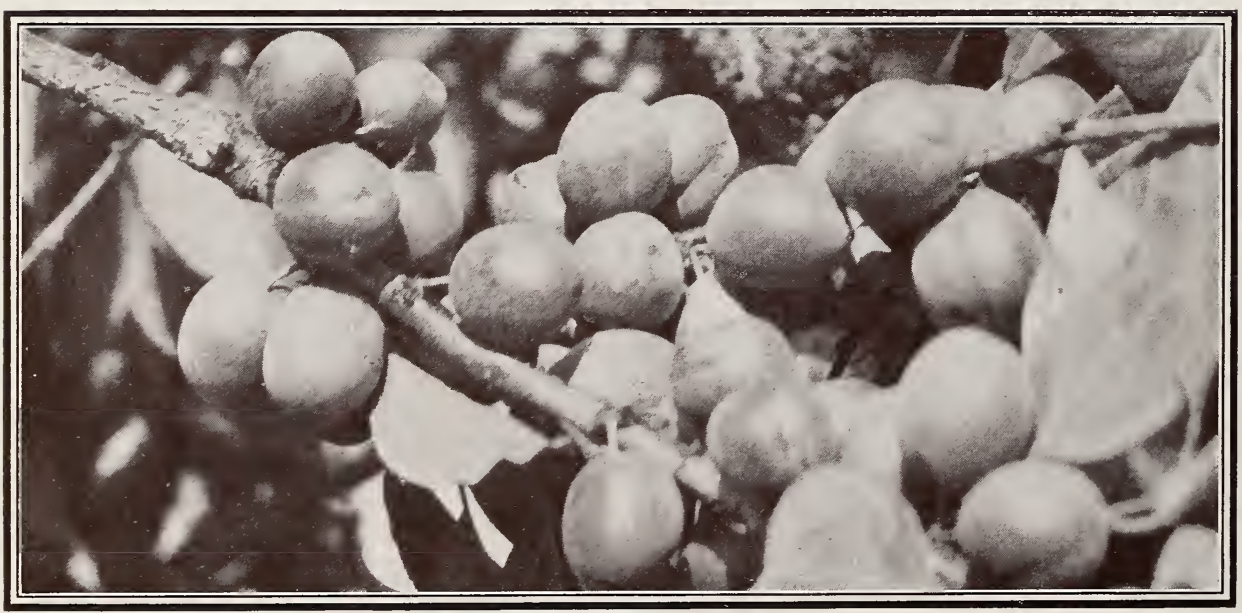

"A P EX" 


\section{New Plumcot-The "Triumph"}

Another wonderful new fruit and almost the exact opposite from Apex in most respects. Trees productive, of weeping habit, with long, slender branches. Fruit apricot-like in form, six inches around, with a purple velvety skin. Finely dotted and mottled scarlet. Flesh firm, apricot-like in texture, deep crimson with lighter shades near the stone. Rich apricot flavor with plum accompaniment. One of the most unique of all fruits, especially as the trees bear fruit where all apricots fail to produce a crop. Ripens August 15th.

Trees, each $\$ 3$; two, $\$ 5$; per ten, $\$ 20$.

\section{New Plumcot-“Corona”}

Fruit beautiful, large, golden yellow, with velvety skin and with a red cheek. Flesh yellow, fairly firm, sweet, delicious. Clingstone. Tree a strong, upright grower. Productive. Ripens here July 25 th.

Trees, each $\$ 3$; two, $\$ 5$; per ten, $\$ 20$.

One each of the three Plumeots, $\$ 6$.

\section{A New Peach-The "Leader"}

The earliest of all the Muir Crawford types, ripening here in July. Unusually vigorous trees, which never fail to produce a full crop of beautiful, smooth, globular, bright yellow fruit, with deep crimson blush; flesh pure yellow, meaty, firm, very sweet and delicious-far superior to any other. Stone exceedingly small-free. Never a trace of mildew or curl leaf. The best very early peach for canning or shipping owing to its earliness, productiveness, globular form, beautiful appearance, firm delicious flesh and long keeping qualities. A peach with all the good qualities of the Muir and Early Crawford combined and with the addition of other new ones. As a home peach, it is also unexcelled.

A few trees each $\$ 1$; two, $\$ 1.50$; per ten, $\$ 6$.

Dormant buds, each $75 \mathrm{c}$; two, $\$ 1$; per ten, $\$ 3.50$.

\section{A New Peach-The "National"}

A giant Muir Crawford peach which like the "Leader" is yellow, but is nearly half covered with deep crimson blush and crimson dots. Tree a strong grower and never failing producer of very firm, nearly globular fruits, excelling either parent. Flesh deepest yellow. Stone small, free. Ripening from ten days to two weeks after the "Leader" and before the old Muirs and Crawfords. Never a trace of mildew or curl leaf. A firm and most delicious peach when eanned and for drying 
or shipping. Extra handsome and extra good also as a market or home peach.

Trees, each $\$ 1$; two, $\$ 1.50$; per ten, $\$ 6$.

\section{A New Almond-The "Palatine"}

The attempt has been made time and again during the past fifteen years to secure the true "Jordan" almond from the European growers, but those so far received are shy bearers or otherwise worthless. Long before these importations were made, I had raised numerous Seedlings from the imported meats and now offer the "Palatine" Jordan which bears deliciously sweet, true "Jordan" almonds in abundance.

Trees, each $\$ 1$; two, $\$ 1.50$; per ten, $\$ 8$.

\section{A New Apple-The "Goldridge"}

Tree a much stronger grower and far better bearer than its parent, the Newtown Pippin.

Fruit large, smooth and as perfect as if turned in a lathe; pale yellow with a crimson blush on sunny side; quality equal to Newtown Pippin with an added aromatic fragrance; ripens earlier, along with Baldwin, Greening and other early Winter apples; unusually handsome fruit.

\section{New Pear-Le Conte Bartlett Hybrid The "Test"}

Some twenty-five years ago I made some experiments in crossing our common pears with the Chinese and Japanese pears. The best result of this is "TEST," which is a large pear, being four inches long by two and a half across. In form much like Bartlett and in quality more like Le Conte, but far better and far more prolific than either. It is simply stupendously productive. Ripens four weeks later than Le Conte. When canned is firm and white and fully equal to or better than Bartlett. To those who desire pears by wholesale every year this will bear the test. Each, $\$ 1$.

OPULENT PEACH. One of the very best of all in quality A few trees $30 \mathrm{c}$ each.

DELICIOUS APPLE. This brings the highest price for its unsurpassed quality. Trees, each $30 \mathrm{c}$; per ten, $\$ 2.50$; per hundred, $\$ 20$.

GIANT PRUNE. Well known shipping prune. Trees, each 30c; per ten, $\$ 2.50$.

SUGAR PRUNE. Well known shipping and drying prune. Trees, each $30 \mathrm{c}$; per ten, $\$ 2.50$. 


\section{MISCELLANEOUS \\ Trees, Shrubs, Vines, Etc.}

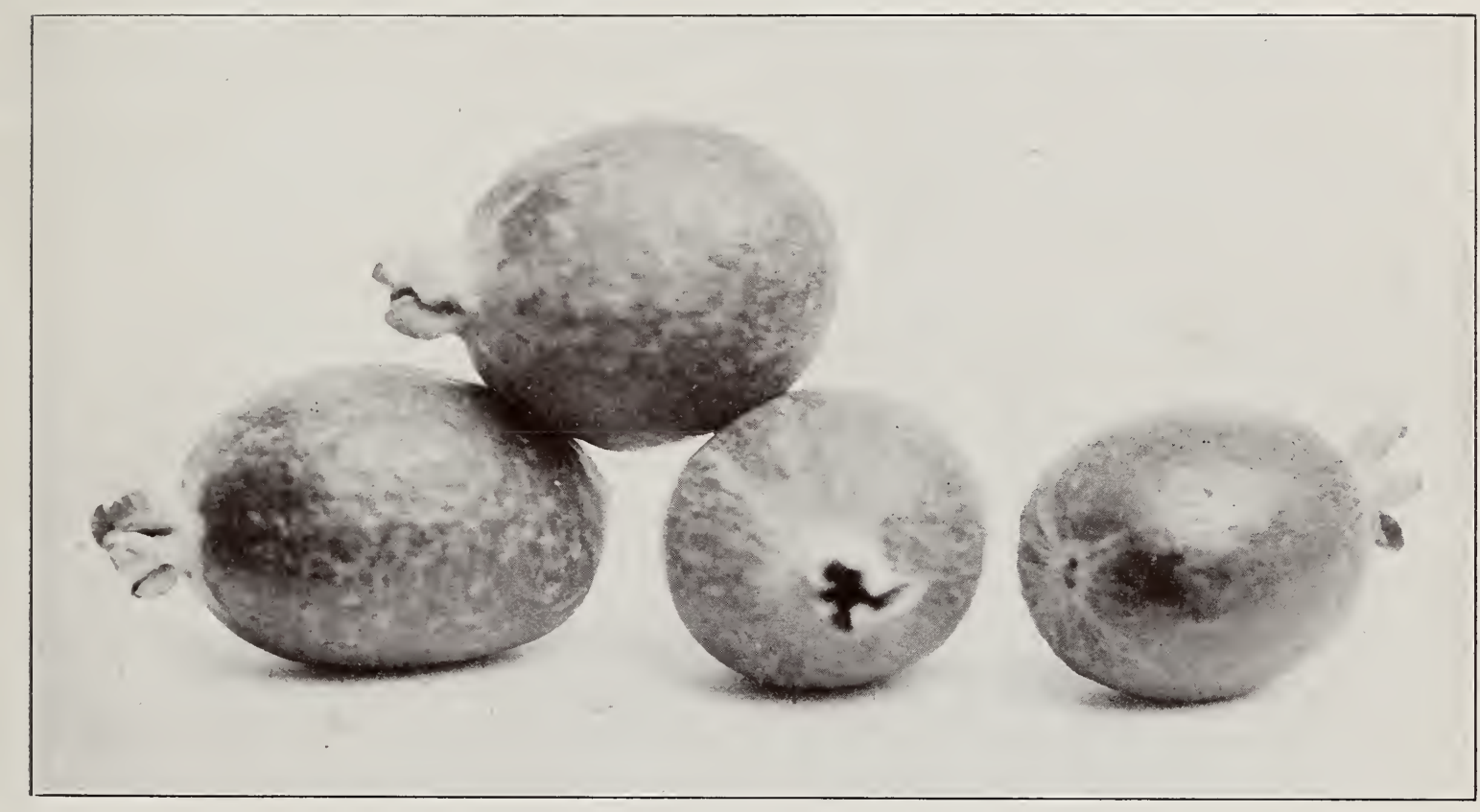

" F EI J O A",

Eastern Wild BLACK CHERRY (Prunus Serotina). Very rapid, upright growing tree producing valuable lumber for cabinet work and house furnishing. Much grown for forestry and for a lawn tree. The variety offered bears unusually large fruit in unusual abundance.

Trees, three to five feet, each 30c; per ten, $\$ 2$.

"CIRUELO," the South American Wild Black Cherry. Like the North American but the tree is evergreen and the fruit much larger and better.

Trees three to four feet, each 50c; per ten, $\$ 3.50$.

Western Wild CHERRY (Prunus demissa). Handsome, compact shrub six to twelve feet high with racemes of handsome deep purple fruit.

Each 30c; per ten, \$2.

CHINESE IMAGNOLIA. Handsome, branched, three-year-old trees, four to six feet. Each 50c; per ten, $\$ 3.50$.

CIRCASSIAN WALNUT (Pterocarya fraxinfolia). Rare and handsome shade and timber tree. Each $75 \mathrm{c}$.

CHINESE VARNISH TREE (Rhus Verniciflua). Each 50c. 
AUSTRALIAN “GRASS TREE.” Rare; very long, slender, wiry leaves; growth something like the Yuccas. Each 50c.

CANADIAN BARBERRY. Large plants. Each 35c.

PURPLE-LEAVED BARBERRY. Ornamental shrub; rich purple foliage. Each $35 \mathrm{c}$; per ten, $\$ 2$; per hundred, $\$ 15$.

CHILIAN BARBERRY (Berberis dulcis). Each $25 \mathrm{c}$.

FEIJOA SELLOWIANA, "FIG-GUAVA." A new evergreen fruiting shrub from Uruguay. Small plants grown in boxes, each 25c. Larger plants from nursery row, each 50c.

PASSIFLORA EDULIS. Australian hard-shell fruiting variety. Each 30c.

"'MAO-LI-DZI." New Chinese trailing plum from the mountains of northwestern China. Bears fine plum-guava like fruit. Each 40c; per ten, $\$ 2$; per hundred, $\$ 15$.

"YANG-TAO" (from Central China). Similar in fruit, but not as hardy; large, handsome foliage. Each 40c; per ten, $\$ 2$.

CHILIAN IVY: New, wholly distinct from the common English Ivy and very much more handsome; beautiful rich dark green coriaceous trifoliate foliage; especially useful for decorations.

Sample foliage will be sent you for examination for a 5 c stamp.

Large nursery grown vines, each $50 \mathrm{c}$; per ten, $\$ 3.50$.

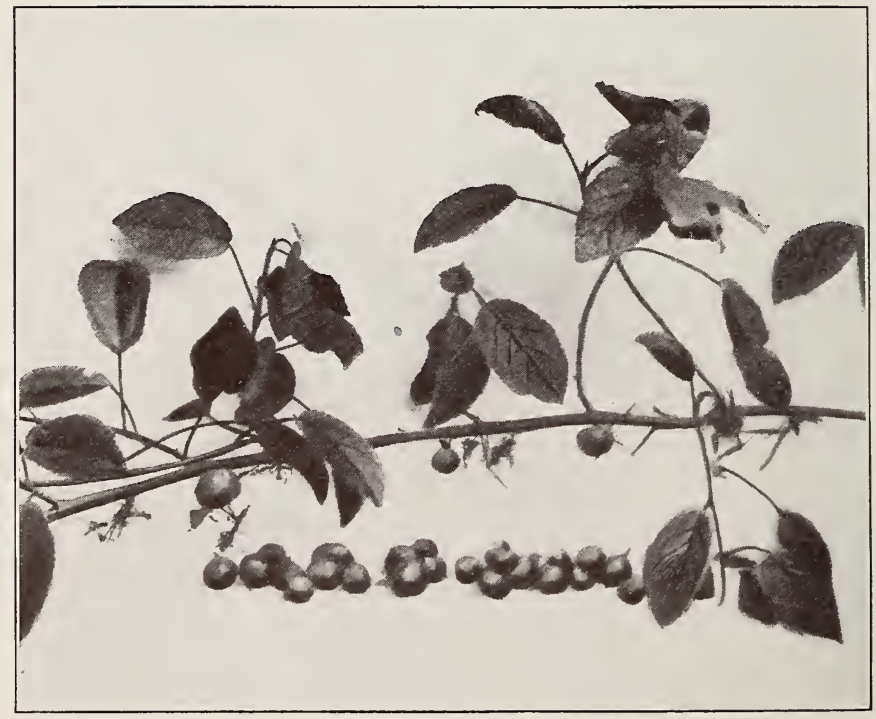

" M A O - L I - D Z I, , 
SOLANUIM JASIMINOIDES. New, large, white. Far handsomer than any heretofore grown. Large clusters, large flowers, rapid grower. Each 40 c; per ten, $\$ 3$.

New Rose "CORONA." Magnificent single; Crimson rambler type with immense clusters of rosy crimson flowers very much resembling Chinese primroses. Climber.

Large plants, each $50 \mathrm{c}$; per ten, $\$ 3.50$.

GIANT GROUND NUT or INDIAN POTATO (Apios Tuberosa). A wholly new ground nut bearing tubers, almost or quite as large as ordinary potatoes.

Tubers, each $30 \mathrm{c}$; per ten, $\$ 1.50$.

BALLOON BERRY (Rubus-?). New, from China. Berries globular, orange color, extremely handsome, an inch or more in diameter, with large central cavity, sweet, mild and refreshing, having much the flavor of the salmon berry. Ripens before strawberries and continues for six weeks or more. For home use; too soft for market. Each 50c; per ten, $\$ 3$.

GIGANTIC ARTICHOKE "SANTA ROSA." This new Artichoke produces the largest heads known and of exquisite quality, the flowers being sometimes over three feet in circumference. Each $40 \mathrm{c}$; per ten $\$ 2$.

LIPPIA REPENS, “DIXIE.' A new compact growing lawn plant for dry, warm climates. Requires less than one-tenth the care and onetenth the water necessary for blue grass lawns. Cuttings for 1 square rod, $\$ 1.50$.

SHASTA DAISY, "ALASKA." The old reliable genuine from headquarters. Well rooted plants, each $20 \mathrm{c}$; per ten, $\$ 1$; per hundred, $\$ 6$; per thousand, $\$ 50$.

BURBANK'S GIANT PERENNIAL LARKSPUR. PLATYCODON, BLUE and WHITE. New Brilliant Crimson PENTSTEMON. ACAN. THUS. ASCLEPIAS tuberosa. HEMEROCALLIS, six varieties. CALO. CASIA (Elephant Ears). CHILIAN Flowering rush.

Any of the above 25c each; per ten, $\$ 1.50$; per hundred, $\$ 10$.

MANY RARE AND BEAUTIFUL CHILIAN, AUSTRALIAN AND ASIATIC SHRUBS, TREES AND VINES: EACH $30 \mathrm{c}$ to 50c, ACCORDING TO SIZES AND VARIETY.

TEN KINDS, ONE EACH \$3.

Santa Rosa, California.

LUTHER BURBANK. 


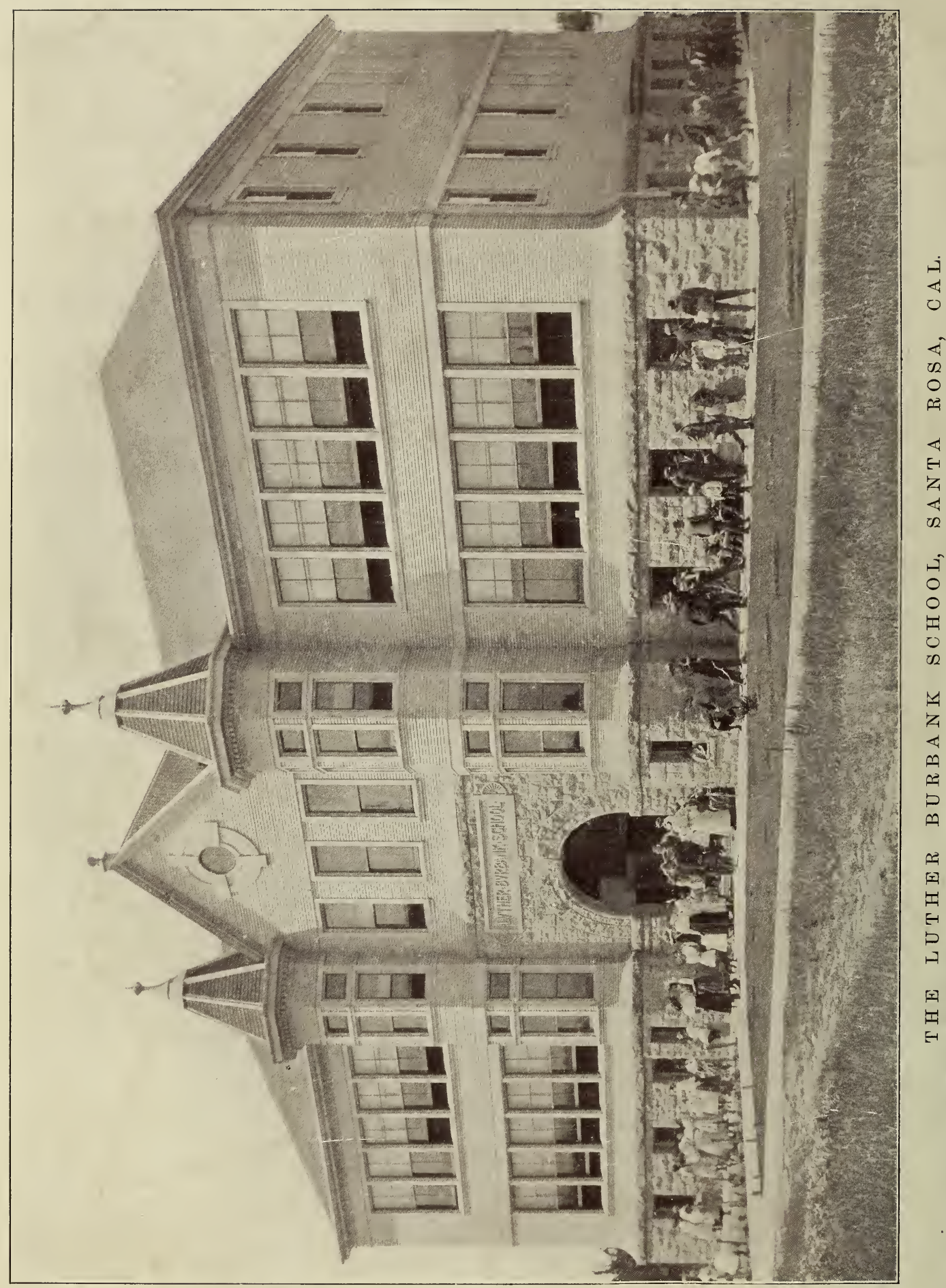

